\title{
EFFECT OF ENTERPRISE DEVELOPMENT SUPPORT PROGRAM ON MARKET PARTICIPATION AND PROFIT EFFICIENCY OF INDIGENOUS VEGETABLE PRODUCTION IN SOUTH AFRICA
}

\author{
MPHAFI, K. ${ }^{1}$ - OYEKALE, A. S. ${ }^{2^{*}}-$ NDOU, P. $^{1}$ \\ ${ }^{1}$ Agricultural Research Council (ARC), Pretoria, South Africa \\ ${ }^{2}$ Department of Agricultural Economics and Extension, North-West University \\ Mafikeng Campus, Mmabatho 2735, South Africa \\ ${ }^{*}$ Corresponding author \\ e-mail: asoyekale@gmail.com; phone: +27-787-144-271 \\ (Received 13 $3^{\text {th }}$ Feb 2019; accepted $10^{\text {th }}$ Apr 2019)
}

\begin{abstract}
African indigenous vegetables (AIVs) play a very significant role in food security of poor households. However, some AIVs are still underutilised in many African countries. The aim of this study was to analyse the effect of farm support program on market participation and profitability of AIV production in South Africa. Data were collected from 86 AIV farmers from South Africa. Probit regression and Stochastic Frontier efficiency analyses were employed for data analyses. The results revealed that infrastructure support assisted farmers to improve participation in markets. In addition, engagement in growing spinach and amaranth vegetables, farm income, gender, cooperative membership and access to EDSP significantly increased the probability of participating in informal markets $(p<0.05)$. Also, the determinants of indigenous vegetable farmers' profit were seed input, land area cultivated, interactions of fertilizer with fertilizer, seed with seed and fertiliser with seed. Profit efficiency was significantly influenced by farm distance, road conditions and access to EDSP. It was concluded that EDSP enhanced farmers' access to informal markets and profit efficiency.
\end{abstract}

Keywords: farm support program, informal market, profit efficiency, African indigenous vegetables, South Africa

\section{Introduction}

African indigenous vegetables (AIVs) play a very significant role in promoting food security for under-privileged households in many African countries (Weinberger and Msuya, 2004). Their importance is underscored as prime facilitators of food security and sources of essential nutrients (Muhanji et al., 2011). Food and Agriculture Organisation (FAO) (2010) noted that as primary sources of food for many people, AIVs are not only associated with provision of vital energy and micronutrients in the diets of isolated communities (Grivetti and Ogle, 2000), but also constitute part of the conglomeration of African indigenous or traditional medicinal plants (Spring, 2015). Some investment opportunities for promoting availability of AIVs have been embarked upon by some African farmers given the growing knowledge of their nutritive values.

However, in sub-Saharan Africa, the potential benefits of AIVs have been overlooked over time due to negligence by consumers (FAO, 2005; Yang and Kedin, 2009). In some developing countries, including South Africa, AIVs hold excellent potentials to improve nutrition and increase households' dietary diversity (Lotter et al., 2014). A study by the World Bank (2010) found that despite the nutritional significance of vegetables, malnutrition remains a problem with stunting greatly affecting children and pregnant women (Fanzo et al., 2013). Inadequate consumption of vegetables is 
resulting in Vitamin A deficiency in about $43.6 \%$ of children and $46 \%$ of pregnant women (Shisana et al., 2014).

In South Africa, there has been a shift towards non-indigenous food by the majority of the population. This has been driven by urbanization and wrong perception of nutritional worth of indigenous food and vegetables (Taleni and Goduka, 2013). Therefore, the government of South Africa has taken some policy measures for promoting production, consumption and marketing of AIVs. The Farmers' Support Program (FSP) was introduced in the mid-1980s and financed by the Development Bank of Southern Africa (DBSA) with the aim of supporting all sub-sectors of agronomy and horticulture agricultural systems. The aim of FSP was to promote structural changes to ensure agricultural commercialisation through the provision of comprehensive agricultural support services and incentives to existing farmers (PSPPD, 2010). In order to support government's efforts, some non-parastatal organisations such as the Agricultural Research Council (ARC) embarked on agricultural programs that are aimed at promoting vegetable production and marketing. ARC's programs are aimed at smallholding crop production, agro-processing, food technology and agricultural commercialisation, among others.

There is dearth of studies on the marketing and significance of AIVs in South Africa. Chetty (2013) conducted a study on the dietary analysis of South African indigenous vegetables and traditional food. The findings did not account for the marketing aspect of vegetable production. Mavengahama et al. (2013) analysed the contributions of indigenous vegetables to food security and nutrition across selected communities in South Africa. They pointed out the significance of indigenous vegetables on households' nutritional status given its high composition of micronutrients.

Many smallholder farmers can benefit from agricultural markets. Markelova et al. (2009) conducted a study on the challenges and constraints faced by smallholder farmers in market participation. The study did not cover the issue of farm profits obtained from participating in agricultural markets. It only focused on identifying barriers and innovations to alleviating constraints and challenges. Another study conducted by Maponya et al. (2015) examined the determinants of participation in agricultural markets in the Eastern Cape province of South Africa. Despite the numerous policies and studies regarding vegetables and their significance to human life, the study of vegetable marketing and profitability in South Africa has not been properly researched. It is, therefore, imperative to examine the effect of enterprise development support program on market participation and profitability of indigenous vegetable farmers in South Africa.

Different studies have identified the factors that limit farmers' production and marketing of vegetables. Okoruwa et al. (2009) identified farm size, access to credit facilities, transportation costs and contact with extension agents as the factors that affect market participation. Randela et al. (2008) reported that age, literacy level, ability to speak English, ownership of transport, access to market information, distance to market, dependency ratio and land size have significant influence on market participation. These constraints constitute the greatest barrier to smallholding agriculture, in terms of having access to high value markets (Vink and Kirsten, 2000). The aim of this study is therefore to analyse how enterprise development support affects marketing and profitability of indigenous vegetable production in South Africa. 


\section{Materials and Methods}

\section{Sampling methods}

The study was conducted in Limpopo, Mpumalanga, Eastern Cape and KwaZuluNatal provinces of South Africa. These provinces are involved in agricultural projects that support the promotion and cultivation of AIVs on commercial basis. The respondents were therefore drawn from those farmers that are growing AIVs namely Amaranth, Spinach and Mustard.

Data were collected with structured questionnaire largely comprising of close-ended questions. Eighty six (86) of AIV farmers were interviewed comprising 41 ARC beneficiaries and 45 non-ARC beneficiaries. The survey was conducted with the assitance of agricultural extension officers from the Department of Agriculture. The questionnaire requested information on demographic and household characteristics of respondents such as age, gender, education and marital status, farm specific characteristics, remittances, form of assistance as well as other major challenges to AIV marketing.

\section{Market Participation Modelling}

Probit model was used to model determinants of market participation. This is a type of regression where the dependent variable can only take two values (Yes coded as 1 and No coded as 0 ). The model estimates the probability that an observation with certain characteristics will fall into a specific category. The model can be specified as follows:

$$
P_{i}^{*}=\beta X_{i}+\mu_{i}
$$

which determines the value of participation by

$$
P_{i}=\left\{\begin{array}{l}
1 \text { if } P_{i}^{*}>0 \\
0 \text { if } P_{i}^{*} \leq 0
\end{array}\right.
$$

where $P_{i}^{*}=$ latent continuous index measuring market participation for the ith farmer. $\beta$ is a vector of estimated parameters. $X_{i}$ is a vector of factors which affect participation which are planted mustard (yes $=1,0$ otherwise), planted spinach (yes $=1,0$ otherwise), planted amaranth (yes $=1,0$ otherwise), market price per $\mathrm{kg}$ (Rand), farm revenue (Rand), distance to markets $(\mathrm{km})$, condition of roads (bad road $=1,0$ otherwise), land area used (hectares), gender (female $=1,0$ otherwise), age of farmers (years), marital status of farmers (married $=1,0$ otherwise), formal education (yes $=1,0$ otherwise), household size, member of cooperative (yes $=1,0$ otherwise), farming experience (years), extension support (yes $=1,0$ otherwise), market linkage (yes $=1,0$ otherwise) EDSP farmers (yes $=1,0$ otherwise). $\mu_{i}$ is the random error term.

\section{Profitability of AIVs modelling}

The profit function was specified as:

$$
\pi(x)=R(x)-c(x)=0
$$


where:

$\pi(x)=$ profit from AIV production

$R(x)=$ total revenue for sale of AIV

$C(x)=$ Cost of associated vegetable farming.

The profit function was estimated with Trans log profit function model as:

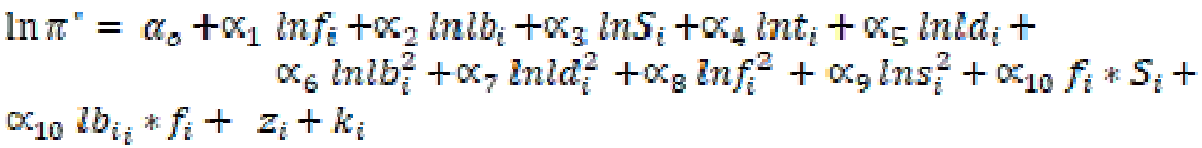

where: In = natural log

$\pi^{\prime}=$ normalised profit

$\alpha_{o}=$ constant parameter

$f i=$ fertiliser, $l b i=$ labour, $s i=$ seed, $t i=$ transport, $l n l b_{i}^{2}=$ labour*labour,

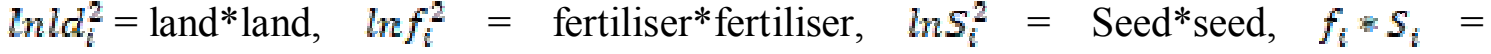
fertiliser*seed, $b_{i} * f_{i}=$ labour*fertiliser and $z_{i}=$ random error term and $k_{i}$ is the inefficiency error term.

The profit inefficiency model is specified as:

$$
k_{i}=\delta+\sum_{k=1}^{14} G_{i k}+m_{i}
$$

where planted spinach (yes $=1,0$ otherwise), planted amaranth (yes $=1,0$ otherwise), market price per $\mathrm{kg}$ (Rand), distance to markets $(\mathrm{km})$, condition of roads (bad road $=1,0$ otherwise), gender (female $=1,0$ otherwise), age of farmers (years), marital status of farmers (married $=1,0$ otherwise), formal education (yes $=1,0$ otherwise), household size, non-farm income (Rand), member of cooperative (yes $=1,0$ otherwise), farming experience (years), extension support (yes $=1,0$ otherwise), market linkage (yes $=1,0$ otherwise) EDSP farmers (yes $=1,0$ otherwise). $\mu_{i}$ is the random error term.

\section{Results and Discussions}

\section{Socio-economic and demographic characteristics of vegetable farmers}

The results in Table 1 show the socioeconomic characteristics of AIV farmers who were being categorized into EDSP benficiaries and non EDSP beneficiaries. The results show that $51 \%$ of the farmers that were supported by EDSP were female, while most of the non-EDSP farmers were male. Similar results had been reported by Ozkan et al. (2000) who found that production of vegetables was associated with female. On the contrary, Mumbi et al. (2006) found that male farmers were taking the lead in the production and marketing of vegetables.

The results in Table 1 further revealed that $59 \%$ of the farmers that were supported by EDSP were more than 40 years old. Some farmers are involved in AIV production as a livelihood strategy for promoting households' nutrition and incomes. The age of AIV farmers as well as their years of farming experience are essential in agricultural market participation (Ramoroka, 2012). In both categories of farmers, those who were married formed a larger proportion than those who were not married. The results are in agreement with those reported by Baba et al. (2010) who found that married farmers participated more in vegetable farming in order to support their families. 
Household size could play an important role in farming as it can be an important source of family labour. About $41 \%$ of the respondents who received support from the Agricultural Research Council (EDSP) had a family size of 4-6 members; an indication that family labour was still a common practice among farmers in order to reduce the cost of hiring labour.Non-EDSP farmers had household sizes of 1-3 members. In South Africa, the average household size is 3.4 members (Stats SA, 2010).

More than half of EDSP farmers (54\%) had secondary education. Masuku and Xaba (2013) highlighted the importance of education in farming and maintained that it enables farmers to adopt change and innovation faster than the uneducated. An average of $62 \%$ of the farmers from EDSP and non-EDSP had farm size of three hectares, while $25 \%$ had ten hectares and more. Land plays an important role in the production of vegetables because it grants farmers an opportunity to expand their farming enterprises. According to Mumbi et al. (2006), the bigger the size of the farm, the higher the yield and the better the chances of the farmer participating in the markets. The average number of years of farming experience was 8 years. Over $30 \%$ of EDSP farmers had substantial farming experience, while non-EDSP farmers had 15 years or more. Farmers with adequate experience are reported by Osmani and Hossain (2015) to participate in the markets better than those who do not have any farming experience.

Table 1. Socio-economic and demographic characteristics of vegetable farmers

\begin{tabular}{|c|c|c|c|c|}
\hline \multirow{3}{*}{ Variable } & \multicolumn{2}{|c|}{ EDSP } & \multicolumn{2}{|c|}{ Non EDSP } \\
\hline & Frequency & Percentage & Frequency & Percentage \\
\hline & $\mathrm{N}=41$ & $\%$ & $N=45$ & $\%$ \\
\hline \multicolumn{5}{|l|}{ Gender } \\
\hline Male & 20 & 48.78 & 26 & 58 \\
\hline Female & 21 & 51.22 & 19 & 42 \\
\hline \multicolumn{5}{|l|}{ Age } \\
\hline $10-20$ & 1 & 2 & 11 & 24 \\
\hline $21-40$ & 16 & 39 & 17 & 38 \\
\hline$\geq 41$ & 24 & 59 & 17 & 38 \\
\hline \multicolumn{5}{|l|}{ Marital status } \\
\hline Married & 36 & 88 & 31 & 69 \\
\hline Not married & 5 & 12 & 14 & 31 \\
\hline \multicolumn{5}{|l|}{ Household size } \\
\hline $1-3$ & 11 & 27 & 20 & 44 \\
\hline $4-6$ & 17 & 41 & 17 & 38 \\
\hline$\geq 7$ & 13 & 32 & 8 & 18 \\
\hline \multicolumn{5}{|l|}{ Education } \\
\hline Primary & 12 & 29 & 5 & 11 \\
\hline Secondary & 22 & 54 & 30 & 67 \\
\hline Tertiary & 2 & 5 & 5 & 11 \\
\hline No formal education & 5 & 12 & 5 & 11 \\
\hline \multicolumn{5}{|l|}{ Farm size } \\
\hline $0.5-5$ ha & 25 & 61 & 28 & 62 \\
\hline $5-10$ ha & 5 & 12 & 7 & 16 \\
\hline$>10$ & 11 & 27 & 10 & 22 \\
\hline \multicolumn{5}{|l|}{ Distance to markets } \\
\hline $0-5 \mathrm{~km}$ & 8 & 19 & 4 & 9 \\
\hline $6-20 \mathrm{~km}$ & 15 & 37 & 5 & 56 \\
\hline $20-38 \mathrm{~km}$ & 18 & 44 & 16 & 36 \\
\hline Road conditions & & & & \\
\hline
\end{tabular}




\begin{tabular}{c|c|c|c|c}
\hline Good & 14 & 34 & 20 & 44 \\
Bad & 27 & 66 & 25 & 56 \\
\hline
\end{tabular}

Source: Field survey, 2016

\section{Determinants of Market Participation}

The results in Table 2 are for econometric modeling of determinants of AIV farmers' particpation in informal markets. The results show that revenue, condition of roads, gender and market linkage had negative relationship with market participation, while growing of Spinach, growing of Amaranths, membership of cooperative and being EDSP farmers showed positive statistically significant relationship $(\mathrm{p}<0.05)$. Growing of Amaranth was statistically significant at 5\% level, while growing of Spinach was statistically significant at 1\% level. Thus, involvement of farmers in growing Spinach or Amaranths increased the probability of participating in informal markets $(p<0.05)$. However, the results of the marginal effect show that the three indigenous vegetables (mustard, spinach and amaranth) produced by farmers were statistically significant and had a positive relation to informal participation in markets. The results imply that growing of each of these vegetables increased the probability of farmers' participation in informal markets.

Table 2. Probit regression estimate and marginal effect of the determinants of informal market participation

\begin{tabular}{c|c|c|c|c}
\hline \multirow{2}{*}{ Variables } & \multicolumn{2}{|c|}{ Probit regression } & \multicolumn{2}{c}{ Marginal effect } \\
\cline { 2 - 5 } & Coefficient & $\mathbf{P}|\mathbf{z}|$ & Coefficient & $\mathbf{P}|\mathbf{z}|$ \\
\hline Planted mustard & 1.0760 & 0.136 & 3628837 & $0.07^{*}$ \\
Planted spinach & 3.6483 & $0.005^{* * *}$ & 0.7618 & $0.000^{* * *}$ \\
Planted amaranth & 3.0860 & $0.038^{* *}$ & 0.8008 & $0.000^{* * *}$ \\
Market price & -0.2142 & 0.13 & -0.0835 & 0.125 \\
Revenue & -0.0002 & $0.027 * *$ & -0.0008 & 0.3 \\
Distance to markets & -0.0049 & 0.189 & -0.0019 & 0.181 \\
Condition of roads & -2.4623 & $0.003 * *$ & -0.7813 & $0.000^{* * *}$ \\
Land use & -0.8773 & 0.161 & -0.3419 & 0.161 \\
Gender & -1.1476 & $0.038^{* *}$ & -0.4213 & 0.19 \\
Age & -0.0087 & 0.697 & -0.0034 & 0.696 \\
Marital status & -0.5947 & 0.283 & -0.2205 & 0.246 \\
Education & 0.4361 & 0.574 & 0.1609 & 0.541 \\
Household size & 0.0487 & 0.571 & 0.0190 & 0.571 \\
Membership of cooperative & 2.7590 & $0.019 * *$ & 0.8192 & $0.000^{* * *}$ \\
Farming experience & 0.0341 & 0.124 & 0.0133 & 0.122 \\
Extension support & -0.1274 & 0.816 & -0.0492 & 0.814 \\
Market linkage & -4.5535 & $0.003 * * *$ & -0.9531 & $0.000^{* * *}$ \\
EDSP farmers & 2.8226 & $0.013 * *$ & 0.8290 & $0.000^{* * *}$ \\
Constant term & 1.9099 & 0.254 & & \\
Number of observations & 86 & & & \\
LR chi 2(19) & 59.73 & & & \\
Prob> chi2 & 0.000 & & & \\
Pseudo R2 & 0.5108 & & & \\
Log likelihood & -28.6034 & & & \\
\hline
\end{tabular}

Source: Field survey, 2016

Hint: ${ }^{* *} \mathrm{p}<0.001 ; * * \mathrm{p}<0.05 ; * \mathrm{p}<0.1 ; \mathrm{CI}=$ Confidence Interval

Increase in farm revenue will decrease the probability of participating in informal markets as farmers will produce more and target formal markets to sell their farm 
produce. This is in agreement with results reported by Moyo (2010), Montshwe et al. (2005) and Magingxa et al. (2005) that an increase in revenue increases participation in formal markets. Similarly, the parameter of condition of roads showed statistical significance with negative sign. According to Hlomendlini (2015), condition of roads influences participation in informal markets negatively. However, as the condition of the roads improves, participation will improve. The negative relationship implies that the probability of participating in informal market decreased by -0.781 when the condition of the road networds is bad. The same results were reported by Ramoroka (2012) who pointed out that the condition of roads is one of the fundamental factors that enables farmers to deliver their produce to the markets.

The age of farmers showed a negative relationship with participation in markets but was statistically significant at 5\% level. This implies that as a farmer grows older, the probability of participating in informal markets also decreases. Arega and Manyong (2007) argued that participation in both formal and informal markets decreases with age because older people consider farming as a way of life rather than business. They are also reluctant to adopt new technologies in farming due to production uncertainties. In this study, a positive and statistically significant relationship between membership of cooperative and market participation was found at 5\% level of significance. Similarly, being an EDSP farmer showed a positive relationship with participation in markets. This is in agreement with results obtained by Sikwela and Mushunye (2013) who found that farmers who received supports performed better in the agricultural food chains. The results of market linkage showed a statistical significance to participation in informal markets $(p<0.01)$. As reported by Rios et al. (2009), farmers who are linked to the market participate better and tend to stay longer for better profits.

\section{AIVs Profitability Analysis}

Increasing profitability is the major production goal of farmers. Various factors affect the level of profit and hence determine the growth potential of farm business. This section provides the results of some of the factors that influence profitability of vegetable farmers. Variables that are assumed to have an impact are then interacted to determine which combinations best influence profitability of farmers positively.

The results in Table 3 show that the coefficient of seed is with negative sign and is statistically significant at $10 \%$. This implies that a $1 \%$ increase in seed will result in a decrease in AIVs profit by $0.2985 \%$. Rachmina et al. (2014) maintained that an increase in seed seldom results in an increase in yields. On the contrary, transportation cost has positive and significant impact on profit with a parameter of $0.2772(\mathrm{p}<0.01)$. Therefore, increase in trnasportation cost by $1 \%$ increases profits from AIV cultivation by $0.2772 \%$. According to Mérel et al. (2006), high cost of transportation affects profitability of farm business. The results further showed that the parameter of land is statistically significant $(\mathrm{p}<0.01)$. This parameter indicates that a $1 \%$ increase in land areas cultivated would decrease profit from AIV cultivation by $0.007 \%$.

Some of the variables were further interacted in order to determine their interactive impacts on AIV profitability. Interaction of labour with itself shows a negative relationship to AIV profit level but statistically significant $(p<0.01)$. This implies that multiplication of currently engaged labour in AIV production will reduce profit. This may occur through increase in labour cost and reduction in the level of output due to excessive intensification. Feroz et al. (2009) found that labour plays an important role in 
farm profitability. According to Sikwela and Mushunye (2013), most of the sampled farmers made use of their household members as labour in order to increase profit.

Multiplication of the quantity of fertiliser shows a statistically significant $(p<0.01)$ negative relationship with profit relaized from AIV production. The results imply that if the amount of fertiliser used in AIV production increases, outputs and profit will decrease. On the contrary, other researchers such as Pender and Gebremedhin (2008), Murthy et al. (2009), and Tilman et al. (2002) found that an increase in fertiliser resulted in increase in profitability. However, multiplication of quality of seeds shows a positive relationship that is statistically significant with profit $(\mathrm{p}<0.01)$. This result is in accordance with that of Abu and Asember (2011). The parameter of interacting fertiliser with seed shows negative relationship with profit. This implies that interaction of these inputs will decrease profit. However, a positive and statistically significant parameter was estimated with interaction of labour and fertiliser $(p<0.01)$. This result implies that an increase in both labour and fertiliser will increase profit.

Table 3. Translog profit function modelling of AIV Production

\begin{tabular}{c|c|c|c|c}
\hline Parameters & Coefficient & $\mathbf{P}|\mathbf{z}|$ & \multicolumn{2}{|c}{$\mathbf{9 5 \%}$ Confidence Interval. } \\
\hline Log fertiliser & .5065765 & 0.221 & -.3050489 & 1.318202 \\
Log labour & .2403793 & 0.333 & -.2457891 & .7265477 \\
Log seed & -.2985276 & 0.069 & -.6204112 & .0233559 \\
Log transport & .2771733 & 0.001 & .1175209 & .4368258 \\
Log land & -.0069876 & 0.000 & -.0103408 & -.0036343 \\
Log labour*labour & -.1424943 & 0.009 & -.2497931 & -.0351956 \\
Log land*land & -.0001865 & 0.612 & -.0009064 & .0005335 \\
Log fertiliser*fertiliser & -.0997815 & 0.021 & -.1843299 & -.015233 \\
Log seed*seed & .1717867 & 0.000 & .0924892 & .2510842 \\
Log feriliser*seed & -.1114082 & 0.007 & -.1930228 & -.0297935 \\
Log labour*fertiliser & .1891201 & 0.003 & .0629148 & .3153254 \\
Constant & 4.522231 & 0.000 & 2.844452 & 6.20001 \\
Number of observations & 86 & & & \\
Wald chi 2(13) & 146.10 & & & \\
Log likelihood & -114.93155 & & & \\
Prob> chi2 & 0.000 & & & \\
\hline
\end{tabular}

Hint: $* * * \mathrm{p}<0.001 ; * * \mathrm{p}<0.05 ; * \mathrm{p}<0.1 ; \mathrm{CI}=$ Confidence Interval

\section{Determinants of AIV Profit Inefficiency}

From the results that are presented in Table 4, distance to the market shows a negative effect on profit inefficiency with a coefficient of $-0.988(p<0.05)$. This result implies that as market distance increases, profit inefficiency decreases. Renkow et al. (2004) had reported similar results. The objective of the condition of roads is to maintain and increase frequency to markets which is important in profit making. It is the major means of transporting agricultural produce from the farms to the markets. In this study, it is revealed that the condition of roads has a positive and significant effect on inefficiency of profit. Thus, inefficiency increased among farmers that had access to bad roads. Ogunniyi (2011) also reported that profit efficiency was affected by the condition roads. This result is also supported by research conducted by Rachmina et al. (2014). With the rapid transformation of marketing systems, traditional marketing channels are being replaced by coordinated links between farmers, processors and retailers. The results of this study show that support on market linkage has a positive and statistically 
significant effect on profit inefficiency. This result is a pointer to inadequate access that AIV farmers are having to formal markets. Presently, majority of them only sold at some informally organized markets. However, Morgan et al. (2009) found that market linkage improves the efficiency of farm profit.

Table 4. Analysis of profit inefficiency of profitability of indigenous vegetable farmers

\begin{tabular}{c|c|c|c|c}
\hline Inefficiency & Coefficient & $\mathbf{P}|\mathbf{z}|$ & \multicolumn{2}{|c}{$\mathbf{9 5 \%}$ Confidence Interval } \\
\hline Planted mustard & -28.91409 & 0.986 & -3246.414 & 3188.585 \\
Planted spinach & -2.013768 & 0.297 & -5.796296 & 1.76876 \\
Planted amaranth & 4.458002 & 0.107 & -.9656879 & 9.881692 \\
Market price & .3412082 & 0.158 & -.1329746 & .815391 \\
Distance & -.0988926 & 0.024 & -.1846088 & -.0131765 \\
Road condition & 4.122046 & 0.044 & .109334 & 8.134758 \\
Gender & 1.495443 & 0.193 & -.7555125 & 3.746399 \\
Age & .0486561 & 0.387 & -.061485 & .1587971 \\
Marital status & -1.37785 & 0.405 & -4.61795 & 1.862249 \\
Education & -1.432988 & 0.487 & -5.470397 & 2.604421 \\
Household size & .3318576 & 0.248 & -.2310566 & .8947719 \\
Non-farm income & .2661136 & 0.867 & -2.855204 & 3.387432 \\
Membership of cooperative & 2.358589 & 0.108 & -.5166361 & 5.233814 \\
Farming experience & -.0727185 & 0.182 & -.1794658 & .0340287 \\
Extension support & 2.534668 & 0.177 & -1.145015 & 6.214351 \\
Market linkage & 6.845036 & 0.066 & -.46571 & 14.15578 \\
EDSP farmers & -4.718239 & 0.187 & -11.72866 & 2.292181 \\
Constant term & -11.68467 & 0.055 & -23.62724 & .2579025 \\
Number of obs & 86 & & & \\
Wald chi 2(13) & 146.10 & & & \\
Log likelihood & -114.93155 & & & \\
Prob> chi2 & 0.000 & & &
\end{tabular}

Hint: $* * * \mathrm{p}<0.001 ; * * \mathrm{p}<0.05 ; * \mathrm{p}<0.1 ; \mathrm{CI}=$ Confidence Interval

\section{Conclusion}

The aim of this study was to examine the effects of enterprise development support program on market participation and profit efficiency of AIV farmers. The results have indicated that the support program enhanced access to informal markets by AIV farmers. This suggests that the program had been able to facilitate marketing of AIV although such linkages are yet to explore some more lucrative formal markets. It was also found that the condition of road influenced access to market and profit inefficiency. These results are reemphasizing the importance of adequate maintenance of feeder roads to the villages on market participation and production efficiency. There should be adequate efforts from government to properly link farmers in some interior villages to urban markets through adequate maintenance and construction of more roads.

\section{REFERENCES}

[1] Abu, O., Asember, D. J. (2011): Opportunities for smallholder Spinach farmers in Nigeria: a Profit efficiency analysis. - Journal of Economics 2(2): 75-79.

[2] Arega, A. D., Manyong, V. M. (2007): The effect of education on agricultural productivity under traditional \& improved technology in Northern Nigeria: An endogenous switching regression analysis. - Empirical Economics 32(1): 141-159. 
[3] Baba, S. H., Zargar, B. A., Ganaie, S. A., Yousuf, S., Sehr, H. (2010): Gender participation in vegetable cultivation in Kashmir valley. - Indian Res. J. Ext. Edu 10(2): 66-69.

[4] Chetty, J. M. (2013): Dietary analysis of South African indigenous vegetables and traditional food assumptions made by nutritionists and the impact on public health outcomes. - Doctoral dissertation, University of Cape Town.

[5] Fanzo, J., Heywood, V., Hunter, D. (2013): Overview of agricultural biodiversity \& its contribution to nutrition \& health. - Diversifying Food and Diets: Using Agricultural Biodiversity to Improve Nutrition \& Health: 35-67.

[6] Feroz, A. N. M., Rashid, M. H. A., Hossain, M. (2009): Profitability analysis of Bagda farming in some selected areas of Satkhira district. - Journal of Progress. Agric. 20(1-2): 221-229.

[7] Food and Agriculture Organisation (FAO). (2005): Marketing Extension guide: Horticultural marketing. - Retrieved from www.fao.org/3/a-a0185e.pdf. Retrieved on $13^{\text {th }}$ August, 2015. p 1-43.

[8] Food and Agriculture Organisation (FAO). (2010): Sustainable pathways: Smallholders and family farmers'. - Retrieved from www.fao.org/.../sustainability_pathways/ .../Factsheet on 13 August, 2015.

[9] Grivetti, L. E., Ogle, B. M. (2000): Value of Traditional Food in Meeting Macro- and Micronutrient Needs: The Wild Plant Connection. - Nutrition Research Reviews 13(1): 31-46.

[10] Hlomendlini, P. H. (2015): Key factors influencing smallholder market participation in the former homelands of South Africa: case study of the Eastern Cape. - Doctoral dissertation, Stellenbosch: Stellenbosch University.

[11] Lotter, D. W., Marshall, M. I., Weller, S., Mugish, A. (2014): African indigenous \& traditional vegetables in Tanzania: production, post-harvest management and marketing. - African Crop Science Journal 22(3): 181-189.

[12] Magingxa, L. L., Alemu, Z., Van Schalkwyk, H. D. (2005): Factors that influencing market access for smallholder irrigators in South Africa. - A paper presented at the 43rd Annual AEASA conference in Polokwane, Limpopo, September, 21-23, 2005.

[13] Maponya, P., Venter, S. L., Modise, D., Van Den Heever, E., Kekana, V. (2015): Determinants of Agricultural Market Participation in the Sarah Baartman District, Eastern Cape of South Africa. - Journal of Human Ecology 50(1): 1-9.

[14] Markelova, H., Meinzen-Dick, R., Hellin, J., Dohrn, S. (2009): Collective action for smallholder market access. - Food policy 34(1): 1-7.

[15] Masuku, M. B., Xaba, B. (2013): Factors Affecting the Productivity \& Profitability of Vegetables Production in Swaziland. - Journal of Agricultural Studies 1(2): 37-52.

[16] Mavengahama, S., McLachlan, M., De Clercq, W. (2013): The role of wild vegetable species in household hood security in maize subsistence cropping systems. - Journal of food Science 5(2): 227-233.

[17] Mérel, P. R., Sexton, R. J., Suzuki, A. (2006): Transportation cost and market power of middlemen: A spatial analysis of agricultural commodity markets in developing countries. $\quad-$ Available at SSRN: https://ssrn.com/abstract=944167 or http://dx.doi.org/10.2139/ssrn.944167.

[18] Montshwe, B. D., Jooste, A., Alemu, Y. G. (2005): An Econometric Analysis of Determinants of Market Participation within the South African Small-Scale Cattle Sub Sector. - A paper presented at the 43rd AEASA conference, Limpopo Polokwane, September 21-23, 2005.

[19] Morgan, N. A., Slotegraaf, R. J., Vorhies, D. W. (2009): Linking marketing capabilities with profit growth. - International Journal of Research in Marketing 26(4): 284-293.

[20] Moyo, T. (2010): Determinants of participation of smallholder farmers in the marketing of small grains and strategies for improving their participation in the Limpopo River Basin of Zimbabwe. - Doctoral dissertation, University of Pretoria. 
[21] Muhanji, G., Roothaert, R. L., Webo, C., Stanley, M. (2011): African indigenous vegetable enterprises and market access for small-scale farmers in East Africa. International Journal of Agricultural Sustainability 9(1): 194-202.

[22] Mumbi, K., Karanja, N., Njenga, M., Kamore, M., Achieng, C., Ngeli, P. (2006): Investigative Market Research: Viable Market Opportunities \& Threats for Urban \&PeriUrban Farmers. - Farm Concern International, Urban Harvest \& International Potato Centre, Nairobi.

[23] Murthy, D. S., Sudha, M., Hegde, M. R., Dakshinamoorthy, V. (2009): Technical efficiency \& its determinants in tomato production in Karnataka, India: Data Envelopment Analysis (DEA) Approach. - Agricultural Economics Research Review 22(2): 215-224.

[24] Ogunniyi, L. T. (2011): Profit efficiency among maize producers in Oyo State, Nigeria. ARPN J. Agric. Boi. Sci. 61(11): 11-17.

[25] Okoruwa, V. O., Akindeinde, A. O., Salimonu, K. K. (2009): Relative economic efficiency of farms in rice production: A profit function approach in North Central Nigeria. - Tropical \& Subtropical Agroecosystems 10(2): 279-286.

[26] Okoye, B. C., Abass, A., Bachwenkizi, B., Asumugha, G., Alenkhe, B., Ranaivoson, R., Randrianarivelo, R., Rabemanantsoa, N., Ralimanana, I. (2016): Effect of transaction costs on market participation among smallholder cassava farmers in Central Madagascar. - Cogent Economics \& Finance 4(1): 1143597.

[27] Osmani, A. G., Hossain, E. (2015): Market participation decision of smallholder farmers \& its determinants in Bangladesh. - EkonomikaPoljoprivrede 62(1): 163.

[28] Ozkan, B., Ediz, D., Ceyhan, V., Goldey, P. (2000): Women's role in the vegetable farming systems in Antalya, Turkey: a gender analysis of labour participation \& decisionmaking in the agricultural sector. - In XIVth International Symposium on Horticultural Economics 536: 419-438.

[29] Pender, J., Gebremedhin, B. (2008): Determinants of agricultural management practices \& impacts on crop production \& household income in the highlands of Tigray, Ethiopia. - Journal of African Economies 17(3): 395-450.

[30] PSPPD. (2011): Program to Support Pro-Poor Policy Development in South Africa. Retrieved from www. presidency.gov.za/.../Program $\% 20$ to\%20Support $\% 20$ ProPoor\%20Policy\%2..Retrieved on $20^{\text {th }}$ June 2016.

[31] Rachmina, D., Daryonto, A., Tambunan, M. (2014): Impact of infrastructure o profit efficiency of vegetable farming in west Java. - Online paper retrieved 19/05/2015. J. ISSAAS 20(1): 77-92.

[32] Ramoroka, K. H. (2012): Participation and utilisation of formal vegetable markets by smallholder farmers in Limpopo: A tobit II approach. - Doctoral dissertation, University of Limpopo (Turfloop Campus).

[33] Randela, R., Alemu, Z. G., Groenewald, J. A. (2008): Factors enhancing market participation by small-scale farmers. - Agrekon 47(4): 451-469.

[34] Renkow, M., Hallstrom, D. G., Karanja, D. D. (2004): Rural infrastructure, transactions costs and market participation in Kenya. - Journal of Development Economics 73(1): 349-367.

[35] Rios, A. R., Shively, G. E., Masters, W. A. (2009): Farm productivity and household market participation: Evidence from LSMS data. - In International Association of Agricultural Economists Conference, August, Beijing.

[36] Shisana, O., Labadarios, D., Rehle, T., Simbayi, L., Zuma, K., Dhansay, A., Reddy, P., Parker, W., Hoosain, E., Naidoo, P., Hongoro, C. (2014): The South African National Health and Nutrition Examination Survey, 2012: SANHANES-1: the health and nutritional status of the nation. - HSRC press.

[37] Sikwela, M. M., Mushunye, A. (2013): The impact of farmer support Programs on household income \& sustainability in smallholder production: A case study of the Eastern 
Cape \&Kwazulu Natal farmers', South Africa. - African Journal of Agricultural Research E 8(21): 2502-2511. http://www.academicjournals.org/AJAR.

[38] Spring, A. (2015): Haiti: Final Country Report. - Arlington, VA: Strengthening Partnerships, Results, and Innovations in Nutrition Globally (SPRING) project.

[39] Taleni, V., Goduka, N. (2013): Creating Spaces for Indigenous Research Around Eziko for Strengthening Sustainable Livelihoods within Rural Contexts. - East London-South Africa, p.205.

[40] Tilman, D., Cassman, K. G., Matson, P. A., Naylor, R., Polasky, S. (2002): Agricultural sustainability and intensive production practices. - Nature 418(6898): 671-677.

[41] Vink, N., Kirsten, J. F. (2000): Market Development \& Smallholder Farmers. A Selective Literature Survey. - Agricultural Economics Research, Policy \& Practice in Southern Africa.

[42] Weinberger, K., Msuya, J. M. (2004): Indigenous vegetables in Tanzania: significance \& prospects (Vol. 600). - AVRDC-WorldVegetableCentre.

[43] World Bank (2010): Agriculture\& Rural Development.Retrieved from data.worldbank.org/topic/agriculture-\&-rural-development.

[44] Xaba, B. G., Masuku, M. B. (2012): Factors affecting the choice of marketing channel by vegetable farmers in Swaziland. - Sustainable Agriculture Research 2.1: 112.

[45] Yang, R. Y., Keding, G. B. (2009): Nutritional contributions of important African indigenous vegetables. African indigenous vegetables in urban agriculture. - Earthscan, London, pp. 105-144. 